\title{
VISIŠKAI NUO ALKOHOLIO PRIKLAUSANČIO LIGOTUMO POKYČIAI LIETUVOJE 2006-2011 METAIS
}

\author{
Mindaugas Štelemėkas, Ingrida Jaselskytė, Vaida Liutkutė, Aurelijus Veryga \\ Lietuvos sveikatos mokslu universiteto Medicinos akademijos Visuomenès sveikatos fakulteto \\ Sveikatos tyrimu institutas
}

Raktažodžiai: alkoholis, ligotumas, alkoholio kontrolè.

\section{Santrauka}

Žalingas alkoholio vartojimas yra susijęs su daugeliu ligų ir sveikatos būklių, todèl užsienio moksliniuose tyrimuose iprasta vertinti alkoholio vartojimo sąlygojamą žalą. Alkoholio vartojimo pasekmėms priskiriama daugiau nei 50 sveikatos būklių, kurios dalinai ar visiškai siejamos su alkoholio vartojimu.

Metodika. Tyrimo tikslas buvo ịvertinti tik su alkoholio vartojimu siejamo ligotumo kaitą 2006-2011 m. Tyrimas atliktas bendradarbiaujant su Valstybiniu psichikos sveikatos centru bei remiantis apibendrintomis 100 proc. nuo alkoholio vartojimo priklausomo ligotumo rodiklių lentelèmis. Analizeje iš viso buvo panaudota 20 būklių, skaičiuotas Spearmen'o koreliacijos koeficientas ir taikyta tiesinè regresinè analizè.

Rezultatai. Analizuojant alkoholio vartojimo sąlygoto ligotumo dinamiką, išsiskiria 2007 m., kuomet buvo pasiektas visiškai alkoholio vartojimo sąlygojamo ligotumo pikas. 2008-2009 m. bendras alkoholio sąlygotas ligotumas krito, o per 2010 ir 2011 $\mathrm{m}$. vèl pradèjo augti. $2006-2011 \mathrm{~m}$. vyrų visiškai alkoholio vartojimo sąlygotas ligotumas buvo apie 4 kartus didesnis nei moterų, o alkoholio vartojimo sąlygoto ligotumo pikas pasiekiamas 45-54 metu amžiaus grupejje. Alkoholio vartojimo sąlygojamas ligotumas gali būti glaudžiai siejamas su alkoholinių gérimų suvartojimo kaita Lietuvoje. Analizuotu laikotarpiu Lietuvoje buvo igyvendinti reikšmingi alkoholio kontrolès politikos pakeitimai, nulèmę alkoholio suvartojimo kaitą.

\section{Ivadas}

Žalingas alkoholio vartojimas yra susijęs su daugeliu ligų ir sveikatos būklių. Išskiriama daugiau nei 50 sveikatos būklių, kurios dalinai ar visiškai siejamos su alkoholio vartojimu, o 20 iš jų - visiškai sąlygojamos alkoholio vartojimo, t.y. tokių būklių iš viso nebūtų registruojama, jei žmonés nevartotu alkoholio [1-3].

Narkotiku, tabako ir alkoholio kontrolès departamento (NTAKD) duomenimis, iki tol augęs alkoholio suvartojimas $2007 \mathrm{~m}$. pasieke 14,74 litru absoliutaus alkoholio vienam gyventojui. 2008 ir 2009 m. absoliutus alkoholio suvartojimas, tenkantis vienam gyventojui, Lietuvoje nustojo augti ir mažèjo, o $2010 \mathrm{~m}$. vèl pradèjo augti ir 2012 m. vienam Lietuvos gyventojui teko vidutiniškai 13,45 litro absoliutaus alkoholio. Lyginant Europos regionus, daugiausia alkoholio suvartojama Centrinejje ir Rytų Europoje, o mažiausiai Šiaurès regionuose [4].

Nuo $2008 \mathrm{~m}$. Lietuvoje buvo uždrausta alkoholio reklama dienos metu radijuje ir televizijoje nuo 6 iki 23 valandos, padidintas alkoholinių gèrimų akcizas, panaikintos mokestinès lengvatos mažiesiems aludariams, sugriežtinta neblaivių vairuotojų atsakomybè, uždrausta prekyba alkoholiu rugsèjo 1-ajją. Nuo $2009 \mathrm{~m}$. buvo dar kartą padidintas akcizas alkoholiniams gérimams bei apribotas alkoholinių gèrimų pardavimo laikas.

Užsienio moksliniuose tyrimuose yra ịprasta nuolat vertinti alkoholio vartojimo sąlygojamą žalą. Lietuvoje atliktuose alkoholio sąlygoto mirtingumo tyrimuose aprašomas ryškus mirtingumo sumažęjimas $2007-2010$ m. 2007 m. 100 tūkst. gyventojų teko 1549 potencialūs prarasto gyvenimo metai (PPGM), 2009 m. PPGM sumažějo iki 872 atvejų 100 tūkst. gyventojų, o $2010 \mathrm{~m}$. tolesnès PPGM teigiamos tendencijos išliko tik vertinant moterų mirtingumo mažejimą, kuris iš esmès lèmè ir bendrą tų metų PPGM mažejimą iki 842 atvejų 100 tūkst. gyventojų [5]. Vertinant su alkoholio vartojimu siejamų išorinių mirties priežasčių naštą Lietuvoje, taip pat stebimas ženklus su alkoholio vartojimu siejamo mirtingumo sumažèjimas 2006 - 2009 m. [6].

Alkoholio vartojimo tiesiogiai sąlygotas ligotumas 
1 lentelė. Visiškai alkoholio vartojimo sąlygojamas ligotumas Lietuvoje 2006-2011 m., atvejų skaičius

\begin{tabular}{|c|c|c|c|c|c|c|c|c|}
\hline \multirow{2}{*}{ Diagnozè } & \multirow{2}{*}{ TLK-10 } & \multicolumn{6}{|c|}{ Alkoholio vartojimo sąlygojamas ligotumas Lietuvoje } & \multirow{2}{*}{ Iš viso } \\
\hline & & 2006 & 2007 & 2008 & 2009 & 2010 & 2011 & \\
\hline $\begin{array}{l}\text { Alkoholio sukeltas pseudo-Kušingo } \\
\text { (Cushing) sindromas }\end{array}$ & E24.4 & 1 & 1 & 0 & 3 & 2 & 4 & 11 \\
\hline Vernikès (Wernicke) encefalopatija & E51.2 & 2 & 2 & 1 & 2 & 3 & 2 & 12 \\
\hline $\begin{array}{l}\text { Psichikos ir elgesio sutrikimai, vartojant } \\
\text { alkoholi }\end{array}$ & F10 & 11731 & 12979 & 11936 & 10145 & 10481 & 11148 & 68420 \\
\hline $\begin{array}{l}\text { Nervų sistemos degeneracija, sukelta } \\
\text { alkoholio }\end{array}$ & G31.2 & 913 & 1178 & 1401 & 1435 & 1562 & 1685 & 8174 \\
\hline Alkoholio sukelta polineuropatija & G62.1 & 1143 & 1366 & 1655 & 1537 & 1623 & 1795 & 9119 \\
\hline Alkoholinè miopatija & G72.1 & 7 & 12 & 12 & 10 & 7 & 8 & 56 \\
\hline Alkoholinė kardiomiopatija & I42.6 & 73 & 107 & 66 & 76 & 61 & 93 & 476 \\
\hline Alkoholinis gastritas & $\mathrm{K} 29.2$ & 118 & 112 & 84 & 73 & 74 & 83 & 544 \\
\hline Alkoholinė kepenų liga & K70 & 1825 & 2247 & 2352 & 2097 & 1955 & 1831 & 12307 \\
\hline Lètinis alkoholinis pankreatitas & K86.0 & 497 & 493 & 511 & 455 & 464 & 543 & 2963 \\
\hline $\begin{array}{l}\text { Vaisiaus ir naujagimio patologija dèl } \\
\text { motinos vartojamo alkoholio }\end{array}$ & P04.3 & 6 & 3 & 1 & 1 & 2 & 0 & 13 \\
\hline $\begin{array}{l}\text { Gimdyvės priežiūra dėl (ịtariamo) vaisiaus } \\
\text { pažeidimo alkoholiu }\end{array}$ & O35.4 & 0 & 3 & 3 & 0 & 1 & 6 & 13 \\
\hline Vaisiaus alkoholinis sindromas (dismorfinis) & Q86.0 & 10 & 16 & 24 & 22 & 21 & 17 & 110 \\
\hline Alkoholio nustatymas kraujyje & R78.0 & 12 & 20 & 19 & 17 & 16 & 20 & 104 \\
\hline Alkoholio toksinis poveikis: etanolis & T51.0 & 874 & 873 & 805 & 616 & 589 & 698 & 4455 \\
\hline Alkoholio toksinis poveikis: metanolis & T51.1 & 28 & 31 & 18 & 18 & 18 & 22 & 135 \\
\hline Alkoholio toksinis poveikis, nepatikslinta & T51.9 & 1619 & 1589 & 970 & 896 & 995 & 1357 & 7426 \\
\hline $\begin{array}{l}\text { Atsitiktinis apsinuodijimas alkoholiu bei jo } \\
\text { poveikis }\end{array}$ & $\mathrm{X} 45$ & 12 & 16 & 20 & 9 & 4 & 14 & 75 \\
\hline $\begin{array}{l}\text { Tyčinis apsinuodijimas ir apnuodijimas } \\
\text { alkoholiu }\end{array}$ & $\mathrm{X} 65$ & 4 & 5 & 9 & 4 & 9 & 4 & 35 \\
\hline $\begin{array}{l}\text { Apsinuodijimas alkoholiu bei jo poveikis, } \\
\text { kai ketinimas nežinomas }\end{array}$ & Y15 & 10 & 9 & 13 & 7 & 20 & 8 & 67 \\
\hline \multicolumn{2}{|l|}{ Iš viso tik vyrai } & 15044 & 16752 & 15664 & 13706 & 14049 & 14999 & 90214 \\
\hline \multicolumn{2}{|l|}{ Iš viso tik moterys } & 3841 & 4310 & 4236 & 3717 & 3858 & 4339 & 24301 \\
\hline \multicolumn{2}{|l|}{ Iš viso } & 18885 & 21062 & 19900 & 17423 & 17907 & 19338 & 114515 \\
\hline
\end{tabular}

paminètas A. Verygos (2010) [7] straipsnyje. Čia taip pat pabrěžiamas akivaizdus alkoholio suvartojimo, alkoholio politikos ir visuomenès sveikatos rodiklių kaitos ryšys tarp 2007 ir vẻlesnių metų. Tačiau pastarajame tyrime buvo analizuojama tik keletas ligotumo rodiklių pokyčių, kurie neatspindi visų tiesiogiai su alkoholio vartojimu siejamų sergamumo pokyčiu.

Darbo tikslas: îvertinti visiškai tik su alkoholio vartojimu siejamo ligotumo kaitą 2006 - 2011 m., apimant 100 proc. su alkoholio vartojimu siejamas TLK-10 diagnozes.

\section{Tyrimo metodai}

Tyrimas atliktas kartu su Valstybiniu psichikos sveikatos centru (VPSC) ir šiame straipsnyje remtasi apibendrintomis visiškai nuo alkoholio vartojimo priklausomo ligotumo rodiklių lentelèmis. Pradinejje duomenų analizèje, sudarant ligotumo pasiskirstymo lenteles, alkoholio vartojimo sąlygojamas ligotumas buvo ịvertintas panaudojant 2006-2011 m. SVEIDRA duomenis, kurie atspindi apie 99 proc. stacionaro ligonių ir apie 90 proc. ambulatoriniu apsilankymų atvejų Lietuvoje. Pradinius duomenis sudare individualūs nuasmeninti ambulatorinių kontaktų ir stacio- 
narizavimo atvejų įrašai iš formų Nr. 025/a-LK ir Nr. 066/ a-LK. Kiekvienais metais tokių individualių įrašų skaičius svyravo tarp 6-7 milijonų, kurie vẻliau tarpusavyje buvo apjungti pagal individualių įrašų identifikacinį numerị. Šie duomenys buvo sugrupuoti pagal pagrindinę diagnozę, amžių ir lytị, suskaičiuotas ligotumo rodiklis ir sudarytos apibendrintos lentelès. Ligotumo rodiklis, tradiciškai pri-

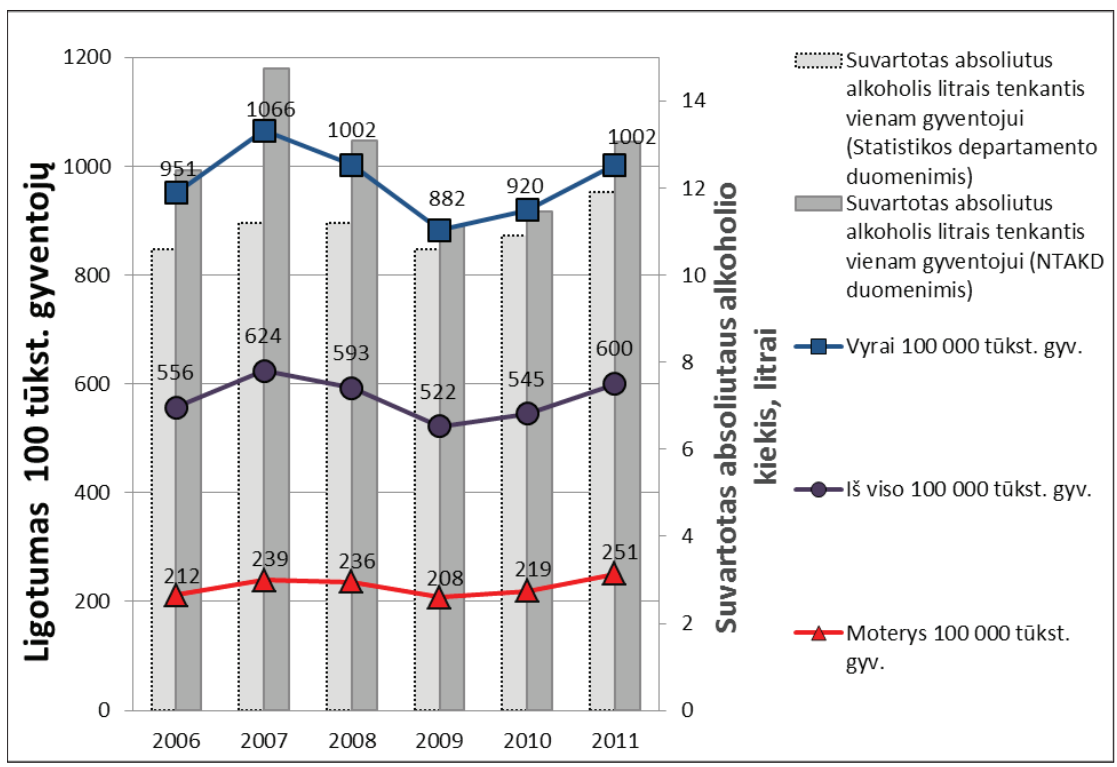

1 pav. Alkoholio suvartojimo ir alkoholio suvartojimo sąlygojamo ligotumo sąsajos Lietuvoje

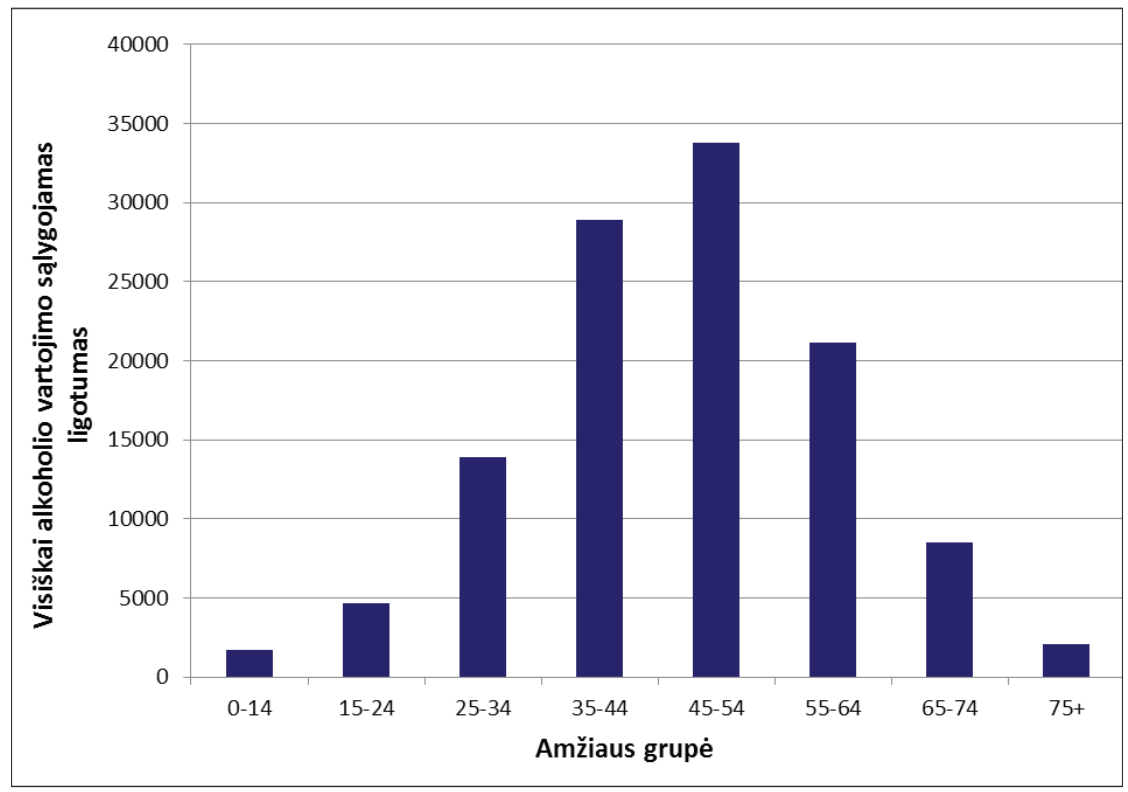

2 pav. Visiškai alkoholio vartojimo sąlygojamas ligotumas atskirose amžiaus grupėse Lietuvoje 2006-2011 m. (atvejų sk.) skiriamas visiškai alkoholio vartojimo sąlygojamiems susirgimams, atspindi asmenis, kuriems atitinkamais kalendoriniais metais buvo rastas bent vienas ambulatorinis ar stacionarinis įrašas su pagrindine diagnoze.

Šiame tyrime visiškai nuo alkoholio vartojimo priklausomoms TLK-10 diagnozèms priskirta iš viso 20 būklių: alkoholio sukeltas pseudo-Kušingo sindromas (E24.4); vernikès encefalopatija (E51.2); psichikos ir elgesio sutrikimai, vartojant alkoholị (F10); nervų sistemos degeneracija, sukelta alkoholio (G31.2); alkoholio sukelta polineuropatija (G62.1); alkoholinè miopatija (G72.1); alkoholinè kardiomiopatija (I42.6); alkoholinis gastritas (K29.2); alkoholinè kepenu liga (K70); lètinis alkoholinis pankreatitas (K86.0); vaisiaus ir naujagimio patologija dèl motinos vartojamo alkoholio (P04.3); gimdyvès priežiūra dèl įtariamo vaisiaus pažeidimo alkoholiu (O35.4); vaisiaus alkoholinis sindromas (Q86.0); alkoholio nustatymas kraujyje (R78.0); etanolio toksinis poveikis (T51.0); metanolio toksinis poveikis (T51.1); nepatikslinto alkoholio toksinis poveikis (T51.9); atsitiktinis apsinuodijimas alkoholiu bei jo poveikis (X45); tyčinis apsinuodijimas ir apnuodijimas alkoholiu (X65); apsinuodijimas alkoholiu bei jo poveikis, kai ketinimas nežinomas (Y15). 2006 - $2011 \mathrm{~m}$. absoliutaus alkoholio suvartojimas (litrais), tenkantis vienam gyventojui, atspindi Lietuvos statistikos departamento ir NTAKD duomenis.

Analizèje skaičiuotas Spearmen'o koreliacijos (r) koeficientas ir taikyta tiesinè regresinè analizè, nurodant regresijos ir determinacijos $\left(\mathrm{R}^{2}\right)$ koeficientus bei pasikliautinuosius intervalus (PI). Skirtumai tarp požymių laikyti statistiškai reikšmingais, kai $\mathrm{p}<0,05$.

\section{Rezultatai ir jų aptarimas}

1 lentelejje pateikiami apibendrinti visiškai alkoholio sąlygojamo ligotumo Lietuvoje rodikliai 2006 - 2011 $\mathrm{m}$. Visais analizuotais metais didžiausią alkoholio sąlygojamo ligotumo 
dalį sudaro psichikos ir elgesio sutrikimai, išsivystę dèl alkoholio vartojimo (F10), alkoholinès kepenų ligos (K70), alkoholio sukeltos polineuropatijos (G62.1) ir alkoholio sukeltos nervų sistemos degeneracijos (G31.2). Dalis ligu diagnozuojamos ne kiekvienais metais ar tèra vos keli atvejai per metus. Vidutiniškai kiekvienais metais visiškai alkoholio vartojimo sąlygotas ligotumas sudare daugiau kaip 19 tūkst. atvejų, o per šešerius analizuotus metus - daugiau kaip 114,5 tūkst. atvejų.

Bendras vyru alkoholio vartojimo sąlygotas ligotumas visais analizuotais metais buvo apie 4 kartus didesnis nei moterų. Didžiausi vyrų ir moterų ligotumo skirtumai buvo vertinant alkoholio sukeltas polineuropatijas ir alkoholio sukeltų nervų sistemos degeneracijas, kur vyrų ligotumo dalis buvo daugiau kaip 4,7 karto didesnè nei moterų.

Alkoholio suvartojimas pasižymi aukšta teigiama koreliacija su alkoholio vartojimo sąlygotomis pasekmėmis: palyginant bendrą ligotumą, tenkantị 100 tūkst. gyv., su Statistikos departamento alkoholio suvartojimo duomenimis $r=0,794 ; p=0,059$; palyginant su NTAKD duomenimis $\mathrm{r}=0,886 ; \mathrm{p}=0,019$. Analizuojant alkoholio vartojimo sąlygoto ligotumo dinamiką 2006 - 2011 m. akivaizdžiai išsiskiria 2007 m., kuriais alkoholio vartojimo sąlygojamas ligotumas pasiekè piką (1 pav.). Vèlesniais metais bendras alkoholio sąlygotas ligotumas krito nuo 624 atvejų 100 tūkst. gyventojų 2007 m., iki 522 atvejų 2009 m., o per 2010 ir $2011 \mathrm{~m}$. vèl kilo ir paskutiniaisiais vertintais metais pasiekè 600 atvejų 100 tūkst. gyventojų. Moterų ligotumo dinamika, nors ir atspindejo bendrą tendenciją, kito nežymiai, o $2011 \mathrm{~m}$. netgi viršijo $2007 \mathrm{~m}$. lygị.

Tiesinès regresinès analizès rezultatai parodè, kad 2006 - $2011 \mathrm{~m}$. laikotarpyje absoliutaus alkoholio suvartojimui padidejus 1 litru (Statistikos departamento duomenimis) bendras alkoholio vartojimo sąlygotas ligotumas tenkantis 100 tūkst. gyv. padidèja 51,8 atvejo $\left(\mathrm{R}^{2}=0,998 ; \mathrm{p}<0,001\right.$; 95 proc. PI: 49,3-54,3). Remiantis NTAKD duomenimis, alkoholio suvartojimui padidejus 1 litru, ligotumas padidèja 43,7 atvejo 100 tūkst. gyv. $\left(R^{2}=0,999 ; p<0,001 ; 95\right.$ proc. PI: 41,8-45,5).

2 pav. apibendrinamas alkoholio vartojimo sąlygoto ligotumo pasiskirstymas atskirose amžiaus grupèse 2006-2011 m. Pikas pasiekiamas 45-54 metų amžiaus grupejje (33769 atvejai), kuomet pikas pasiekiamas pagal daugumą dažniausių su alkoholiu siejamų diagnozių, tokių kaip alkoholio sukeltos polineuropatijos, alkoholio sukeltos nervų sistemos degeneracijos, alkoholinès kepenų ligos ir nepatikslinti alkoholio toksiniai poveikiai. Iš esmès šiai amžiaus grupei galima priskirti ir psichikos bei elgesio sutrikimus vartojant alkoholi, nes čia atvejų dažnis nežymiai skiriasi nuo 35-44 metu amžiaus gru- pės, kurioje pasiekiamas alkoholinių psichozių pikas. Vis dèlto daugiausia etanolio toksinio poveikio atvejų (T51.0) registruojama 15-24 metų amžiaus grupejje, kur 2006-2011 m. iš viso buvo registruoti 1299 apsinuodijimai etanoliu. 0-14 metu grupeje taip pat atsiduria nemaža dalis apsinuodijimų alkoholiu (T51.0 - 879 atvejai; T51.9 - 449 atvejai). I 0-14 m. amžiaus grupę patenka 100 vaisiaus alkoholinio sindromo (VAS) atvejų, registruotu per 20062011 m. (2 pav.).

Šio tyrimo rezultatai parodo, kad pastarujų metu alkoholinių gerimų suvartojimo kaita persidengia ne tik su alkoholio vartojimo sąlygojamu mirtingumu $[5,6]$, bet ir su ligotumu (1 pav.). $2007 \mathrm{~m}$. buvo pasiektas alkoholio suvartojimo pikas, kuomet, NTAKD duomenimis, vienam gyventojui teko 14,7 litro absoliutaus alkoholio (11,2 litrai, Lietuvos statistikos departamento duomenimis). Tais metais buvo pasiektas ir visiškai alkoholio vartojimo sąlygojamo mirtingumo, ir visiškai alkoholio sąlygojamo ligotumo pikas.

2009 m. alkoholio suvartojimas sumažejo iki 11,3 litro (10,6 litro, Lietuvos statistikos departamento duomenimis). Nuo 2007 iki 2009 m. visiškai alkoholio sąlygojama mirtingumo našta išreikšta PPGM artèjo prie dvigubo sumažèjimo [5], o ligotumas sumažèjo beveik penktadaliu (1 pav.). Nuo $2010 \mathrm{~m}$. tiek alkoholio suvartojimas, tiek ligotumas pradejo augti. Alkoholio vartojimo sąlygojamo ligotumo mažejjimą per 2008 ir 2009 m. galima sieti su alkoholio kontrolès sugriežtinimu, kuomet įrodymais grịstų alkoholio kontrolès politikos priemonių diegimas (alkoholio akcizo didinimas, dalinis alkoholio reklamos uždraudimas, sugriežtinta neblaivių vairuotojų kontrolè) sąlygojo alkoholio vartojimo sumažèjimą.

Tuo tarpu 2010 - $2011 \mathrm{~m}$. Lietuvos alkoholio kontrolès politikoje pastebètos neigiamos tendencijos: $2010 \mathrm{~m}$. pabaigoje buvo bandyta sumažinti akcizini alkoholiniu gėrimų apmokestinimą ir pailginti prekybos alkoholiu laiką nuo 22 iki 24 val., o $2011 \mathrm{~m}$. pabaigoje buvo atšauktas tureję̨s įsigalioti visiškas alkoholio reklamos draudimas, potencialiai galèjęs turèti reikšmingą ịtaką alkoholio suvartojimo mažejimui ateityje. Svarbu pabrèžti, kad buvo taikomasi ir iš dalies pavyko (reklamos draudimo atšaukimas) panaikinti pačias efektyviausias moksliniu požiūriu alkoholio kontrolès politikos priemones. Papildomų efektyvių priemonių, galinčių sistemingai toliau mažinti alkoholio suvartojimą, per 2010 ir $2011 \mathrm{~m}$. nebuvo įdiegta. Iš kitos pusès, $2011 \mathrm{~m}$. Lietuvoje pradèjo gerèti ekonominè situacija (vèl pradèjo augti gyventojų uždarbis) ir tai prisidejo prie santykinès alkoholinių gërimų kainos mažejimo (kuomet už vidutinị atlyginimą galima įpirkti daugiau alkoholio) [8].

Aptariant atskiras visiškai alkoholio vartojimo sąlygo- 
jamas būkles reikia pabrèžti, kad alkoholio sąlygojamas ligotumas nebūtinai atsispindi iš karto tais metais, kuomet pasikeičia bendras alkoholio suvartojimo lygis. Taip pat vertinant alkoholio suvartojimo pokyčius svarbu atkreipti dèmesị i alkoholinių gèrimų rūšis, kurių vartojimo išaugimas galèjo atsispindèti bendrame alkoholio suvartojimo kontekste. Pavyzdžiui, Lietuvos statistikos departamento duomenimis, alkoholinių gèrimų pardavimų augimas 2010 $\mathrm{m}$. daugiausia pasiektas dèl augusio silpnesnių alkoholinių gẻrimų vartojimo (alaus, fermentuotų gèrimų suvartojimas augo, spiritinių gèrimų - vis dar mažejo). $2011 \mathrm{~m}$. prie bendro alkoholio suvartojimo augimo ženkliai prisidejo stipriujų gèrimų vartojimo šuolis, o šių gèrimų vartojimas visuomet ryškiau atsispindi sveikatos rodikliuose [9].

Kita problema, vertinant alkoholio vartojimo sąlygojamą naštą, yra sveikatos rodiklių statistikos kokybė. Tradiciškai ligotumas psichikos ir elgesio sutrikimais vartojant alkoholi (F10) yra vertinamas kaip viena iš greičiausiai ir tiksliausiai alkoholio daromos žalos kaitą atspindinčiu būklių, tačiau visiškai kitokia situacija yra tikètina Lietuvoje diagnozuojant alkoholini vaisiaus sindromą (VAS). Nepaisant aukšto alkoholio suvartojimo lygio, oficialiojoje ligotumo statistikoje atsispindi vos 123 VAS atvejai (P04.3 ir Q86.0) per 6 analizuotus metus.

VAS yra liga, sąlygojanti didelị sveikatos priežiūros ir socialinių paslaugų poreikị daugelio metų perspektyvoje, o tai be abejonès nulemia dideles valstybès išlaidas ateityje. Iki šiol išsamesnių tyrimų apie VAS paplitimą Lietuvoje nebuvo atlikta [10], o šis tyrimas iškelia galimas gilesnes VAS diagnozavimo ir atspindejimo oficialiojoje statistikoje problemas. Todèl išlieka būtinybė atlikti detalesnius tyrimus ịvertinant VAS dažnị bei šio sindromo sukeliamą socialinę ir ekonominę naštą Lietuvoje.

\section{Išvados}

1. Analizuojant alkoholio vartojimo sąlygojamo ligotumo dinamiką, $2007 \mathrm{~m}$. išsiskiria kaip metai, kuomet buvo pasiektas visiškai alkoholio vartojimo sąlygojamo ligotumo pikas. $2008-2009 \mathrm{~m}$. bendras alkoholio sąlygotas ligotumas krito, o per 2010 ir $2011 \mathrm{~m}$. vèl pradejjo augti.

2. Alkoholio vartojimo sąlygojamas ligotumas gali būti glaudžiai siejamas su alkoholinių gèrimų suvartojimo kaita Lietuvoje. Analizuotu laikotarpiu Lietuvoje buvo igyvendinti reikšmingi alkoholio kontrolès pakeitimai, nulëmę alkoholio suvartojimo kaitą.

3. $2006-2011 \mathrm{~m}$. vyrų visiškai alkoholio vartojimo sąlygotas ligotumas buvo apie 4 kartus didesnis nei moterų, o alkoholio vartojimo sąlygoto ligotumo pikas pasiekiamas 45-54 metų amžiaus grupejje.

\section{Literatūra}

1. Rehm J, Baliunas D, Borges GLG, Graham K, Irving H, Kehoe $\mathrm{T}$, et al. The relation between different dimensions of alcohol consumption and burden of disease: an overview. Addict. Abingdon Engl. 2010;105(5):817-43.

2. Grant I, Springbett A, Graham L. Alcohol attributable mortality and morbidity: alcohol population attributable fractions for Scotland - ScotPHO. 2009 [žiūrèta 2013 m. gegužès 06 d.]. Prieiga per internetą: $<$ http://www.scotpho.org.uk/publications/reportsand-papers/486-alcohol-attributable-mortality-and-morbidityalcohol-population-attributable-fractions-for-scotland->.

3. Jones L, Bellis MA, Dedman D, Sumnall H, Tocque K. Alcoholattributable fractions for England (Alcohol-attributable mortality and hospital admissions). 2009 [žiūrèta 2013 m. gegužès 06 d.]. Prieiga per internetą: $<$ http://www.alcohollearningcentre. org.uk/Topics/Browse/Data/?parent=4644\&child=4911 $>$.

4. Alcohol in the European Union. Consumption, harm and policy approaches. World Health Organization. 2012 [žiūrèta 2013 m. gegužès 07 d.]. Prieiga per internetą: <http://www.euro.who.int/ en/what-we-publish/abstracts/alcohol-in-the-european-union.consumption,-harm-and-policy-approaches>.

5. Štelemėkas M, Veryga A. Alkoholio vartojimo nulemtų prarastų potencialiu gyvenimo metų kaita Lietuvoje 2003-2010 metais. Visuomenès sveikata. 2012;4(59):26-32.

6. Sauliune S, Petrauskiene J, Kalediene R. Alcohol-Related Injuries and Alcohol Control Policy in Lithuania: Effect of the Year of Sobriety, 2008. Alcohol and Alcoholism. 2012.

7. Veryga A. Alkoholio vartojimo ir gyventojų sveikatos rodiklių sąsajos Lietuvoje. Gastroenterol. ir hepatol. 2010;1(4):8-11.

8. Lietuvos statistikos departamentas. Rodiklių duomenų bazè. Disponuojamųjų piniginių mėnesinių pajamų alkoholiniams gérimams perkamoji galia. 2013 [žiūrèta 2013 m. gegužès 10 d.]. Prieiga per internetą: <http://osp.stat.gov.lt/statistiniurodikliu-analize $1>$.

9. Lietuvos statistikos departamentas. Rodiklių duomenų bazè. Alkoholinių gèrimų pardavimas prekybos ir maitinimo įmonėse. 2013[žiūrèta 2013 m. gegužès 10 d.]. Prieiga per internetą: $<$ http://osp.stat.gov.lt/statistiniu-rodikliu-analizel $>$.

10. Kalinauskienė O, Liubšys A. Vaisiaus alkoholinis sindromas (VAS). Sveikatos mokslai, 2012;22(6):95-9.

\section{PREVALENCE OF FULLY AL COHOL ATTRIBUTABLE CONDITIONS IN LITHUANIA 2006-2011 \\ M. Štelemėkas, I. Jaselskytė, V. Liutkutė, A. Veryga}

Key words: alcohol, prevalence rate, alcohol control.

Summary

Harmful use of alcohol is causing many negative effects, and it is essential to continuously analyze the burden of alcohol in countrywide and international studies. Alcohol is attributable to more than 50 health conditions, which may be partly or fully caused by alcohol.

Methods. The aim of the study was to evaluate the change of 


\section{4}

prevalence of fully alcohol attributable conditions during the period of 2006-2011. The research was performed in collaboration with the State Mental Health Center, and the analysis was based on the summarized prevalence rate data originally received from the Lithuanian morbidity database SVEIDRA. The analysis covers the prevalence data based on 20 fully alcohol attributable conditions.

Results. In 2007 the prevalence of fully alcohol attributable conditions reached its peak. In 2008 and 2009 it had declined, and in 2010 and 2011 it had started to rise again. The close links may be drawn between prevalence of alcohol attributable conditions and overall alcohol consumption in Lithuania. In 2007 the significant toughening of alcohol control policy has been introduced that came into effect in 2008 and 2009, and resulted into the decline of alcohol consumption. In 2006-2011 the prevalence of fully alcohol attributable conditions was in average 4 times higher among men than among women, and reached its peak in people between 45 and 54 years old.

Correspondence to: mindaugas.stelemekas@gmail.com

Gauta 2013-09-24 